DO I: $10.7242 / 2658-705 X / 2020.2 .3$

УДК 579.222 .2

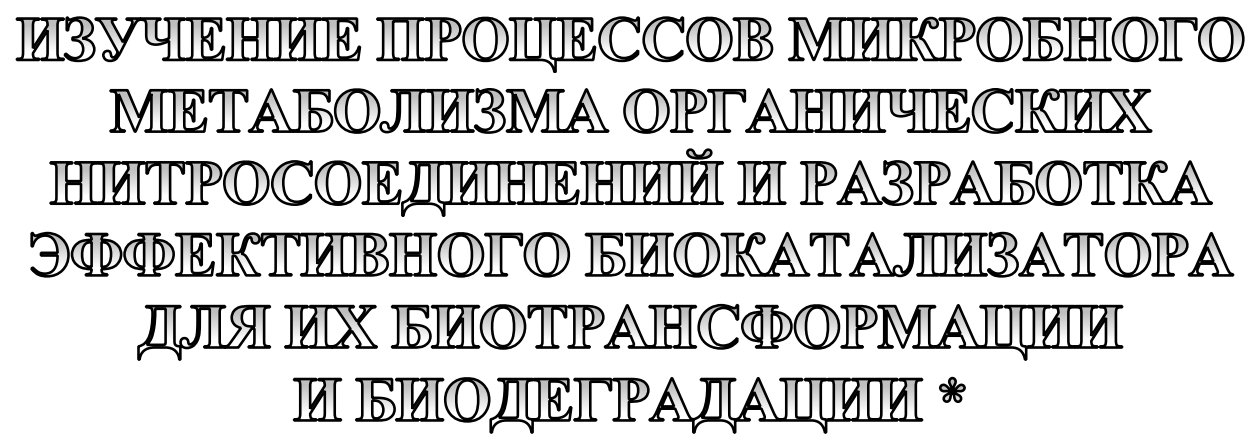

В.А. Демаков, Институт экологии и генетики микроорганизмов УрО РАН

А.Ю. Максимов, Институт экологии и генетики микроорганизмов УрО РАН

Ю.Г. Максимова, Институт экологии и генетики микроорганизмов УрО РАН

А.И. Халитова, Пермский федеральный исследовательский иентр УрО РАН

А.В. Шилова, Пермский федеральный исследовательский иентр УрО РАН

А.С. Литасова, Пермский федеральный исследовательский иеентр УрО РАН

Ю.А. Павлова, Институт экологии и генетики микроорганизмов УрО РАН

С.В. Козлов, Институт экологии и генетики микроорганизмов УрО РАН

Г.В. Овечкина, Институт экологии и генетики микроорганизмов УрО РАН

В результате селекции из природных и техногенно-измененных сред выделены сообщества аэробных гетеротрофных бактерий, способные к использованию труднометаболизируемых органических нитратов (коллоксилин, нитрофенол, нитробензол, динитробензол) В качестве источников углерода и/или азота. Получены активные культуры, идентифицированные как актинобактерии родов Rhodococcus (Rhodococcus erythropolis, Rhodococcus ruber, Rhodococcus rodnii), Arthrobacter, Gordona, бациллы видов Bacillus pumilus и Bacillus thuringiensis, а также протеобактерий Pseudomonas fluorescens, Pseudomonas putida и Pseudomonas extremaustralis, обладающие высокой биодеградативной активностью по отношению к нитроцеллюлозе и ароматическим нитросоединениям.

Проведен метагеномный анализ микроценозов техногенно-измененных грунтов и производных стоков пермских химических предприятий, использующих нитросоединения ФГУП: «Пермский пороховой завод», ОАО «Соликамский завод «Урал», ОАО «Камтэкс-Химпром», а также естественных сред - рек и карстовых озер, природных дерново-луговых и подзолистых почв. В результате ПЦР-анализа у активных культур протеобактерий обнаружены гены нитроредуктаз, характерные для некоторых представителей рода Pseudomonas. Показано, что выделенные изоляты Pseudomonas и Rhodococcus обладают амидазной активностью и имеют гены амидаз известных типов.

\footnotetext{
* Статья подготовлена при финансовой поддержке гранта РФФИ 16-44-590359 р а «Исследование процессов микробного метаболизма органических нитросоединений с применением данных геномных и метагеномных исследований и разработка эффективного биокатализатора для их биотрансформации и биодеградации».
} 
Исследована кинетика роста активных культур с использованием органических нитратов в качестве субстрата. Определено влияние условий культивирования (температура, $\mathrm{pH}$, солевой состав) на скорость роста, прирост биомассы и активность биодеградации нитросоединений. Показано, что высокоактивные культуры Pseudomonas fluorescens, $P$. putida, $R$. erythropolis в оптимальных условиях способны деполимеризовать коллоксилин с высокой скоростью - до 0,5 г/1гс.в. клеток/ сут. Установлено, что продуктами биотрансформации коллоксилина микробными сообществами являются биогенные органические амины и амиды, что дает возможность получать в процессе биодеградации неприродных нитросоединений субстанцию для азотсодержащего органического удобрения.

Ключевые слова: бактерии, биокатализ, биоочистка, биотрансформация, нитросоединения, нитротолуол, нитроцеллюлоза, ТНТ.

Использование ферментов и их продуцентов в сфере биокатализа и биотрансформации в настоящее время является одним из важнейших направлений биотехнологии. Эти способы применяются для получения различных практически значимых химических веществ пищевых и кормовых добавок, фармацевтических препаратов, мономеров для полимерной химии и других. Также в биологических системах есть возможность энантиомерного разделения соединений различных классов: спиртов, эфиров, аминокислот и т.д. Важнейшими для решения экологических проблем являются процессы биодеградации и утилизации химических поллютантов, таких как органические нитрилы. В основе всех этих приложений лежат ферментативные реакции, которые во многих случаях протекают исключительно быстро и специфично, а в случае ассимметрических соединений зачастую стереоспецифично. Преимущества биокатализа заключаются в возможности его проведения при обычных значениях давления и $\mathrm{pH}$, в водной среде, без применения агрессивных компонентов, в его простоте, высокой скорости реакции и специфичности. Для эффективной биотрансформации чаще всего не требуется выделять ферменты в чистом виде. Однако получение биомассы может быть сопряжено с рядом трудностей, обусловленных одновременным протеканием многих ферментативных реакций, что может приводить к образованию побочных продуктов, иногда составляющих значительное количество [15, с. 1-7].

Большой практический интерес представляют продуценты ферментов, ответственных за метаболизм азотсодержащих ароматических соединений, таких как нитропроизводные. В частности, актуальной проблемой является биотрансформация нитробензолов, нитротолуолов, тринитротолуола, нитратов глицерина и целлюлозы. Преобладающей сферой применения нитроорганических соединений является лакокрасочная и оборонная промышленность. Из-за массового производства и использования эти токсичные вещества представляют серьёзную опасность для природы и человека. В связи с этим важной является задача утилизации токсичных нитросоединений и/или трансформации таких отходов с получением новых промышленно значимых веществ [2, с. 210-280; 4, с. 10-23].

В связи с развитием биокаталитических и биосинтетических технологий большой интерес исследователей вызывает поиск продуцентов новых ферментов, различающихся каталитическими свойствами, сравнение генов и аминокислотных последовательностей данных ферментов с целью изучения их разнообразия и распространения определённых структурных типов у различных бактерий, эволюционной изменчивости, последующего определения взаимосвязи структуры и функции, 
механизмов экспрессии белков, уточнения механизмов их действия, структуры фермента и ее роли в катализе [9, с. 382-389].

Успешное применение микроорганизмов в биокаталитических технологиях зависит от свойств биокатализаторов: скорости гидролиза субстрата, $\mathrm{pH}-$ и температурного оптимумов активности ферментов, субстратной избирательности, оптимального состава рабочей среды. Разные ферменты существенно различаются по этим свойствам, поэтому подобная характеристика фермента помогает оценить перспективы использования продуцентов. В связи с вышеизложенным селекция и изучение бактерий - активных продуцентов ферментов - является актуальным направлением микробиологических исследований $[4$, с. 10-19; 9, с. 382-388, 15, с. 2-8].

Нитроредуктазы - семейство ферментов, которое состоит из группы флавинмононуклеотид (ФМН) - или флавинадениндинуклеотид (ФАД) - зависимых ферментов, которые способны трансформировать нитроароматические и нитрогетегоциклические соединения, производные нитрозозамещенных соединений $\mathrm{c}$ помощью восстановления никотинамидадениндинуклеотида $(\mathrm{NAD}(\mathrm{P}) \mathrm{H})$. Эти ферменты встречаются у разных видов бактерий и, в меньшей степени, у эукариот. Нитроредуктазы играют центральную роль в активации нитросоединений и имеют высокий потенциал практического применения [18, с. 250-256; 20, с. 528-532].

Нитрозамещенные соединения в основном производятся в промышленных процессах или других видах антропогенной деятельности и являются значимой группой веществ, загрязняющих окружающую среду. Опасность этих соединений для здоровья человека обусловлена тем, что их метаболизм приводит к образованию мутагенных метаболитов с мощным генотоксическим действием и к генерации активных форм азота видов, которые легко вступают в реакцию с биологическми макромолекулами.

Преобладающими сферами применения нитратов аренов являются производство красителей, лакокрасочная и оборонная промышленность. Из-за массового производства и использования многие места вблизи таких производств оказались сильно загрязнены этими соединениями как в России, так и за рубежом [12, с. 387-390].

В частности, такие места загрязнения и сточные воды, содержащие нитросоединения, имеются в Пермском крае. Растущее беспокойство по поводу здоровья и экологических угроз, связанных с использованием лакокрасок и взрывчатых веществ, привели к расширению исследований их токсикологии. ТНТ имеет высокий собственный токсический потенциал для экосистем, в том числе для людей, а также водных и наземных организмов [8, с. 70-74], и является потенциальным человеческим канцерогеном класса С по данным агентства по охране окружающей среды США. Токсичность тротила для млекопитающих зависит от биовосстановительной активации токсичных гидроксиламинои аминокислотных метаболитов, с образованием активных форм кислорода посредством окислительно-восстановительных реакций [11, с. 296-298]. Некоторые эпидемиологические исследования и эксперименты на животных показали, что ТНТ проявляет репродуктивную токсичность посредством окислительного повреждения ДНК при участии его метаболитов. В частности, исследована биотрансформация и биодеградация нитросоединений штаммами видов Brevibacterium, Micobacterium, Pseudomonas fluorescens, Rhodococcus erythropolis и др. [13, с. 387-390; 16, с. 500-505; 17, с. 256-257]. В последнее десятилетие произошло существенное расширение знаний о биотрансформации ТНТ на генетическом и биохимическом уровне и разработка применения этих процессов в области биотехнологий. Новый импульс исследования в области биокатализа нитросоединений получили благодаря развитию метагеномных исследований [21, c. $1335-1348 ; 22$, с. $13-22 ; 23$, с. 1-5].

Таким образом, несмотря на длительную историю исследования процессов биотрансформации нитроорганических 
соединений, развитие данного направления получило новый импульс благодаря возможности использования современных молекулярных методов исследования, включая метагеномный анализ. Актуальными в настоящее время являются выявление новых генов и ферментов метаболизма органических нитратов, сравнительное изучение их структуры, функциональных и кинетических особенностей, получение новых штаммов-биодеструкторов и продуцентов таких ферментов с использованием новых молекулярных технологий анализа и конструирования.

Настоящее исследование было направлено на определение особенностей и закономерностей микробного метаболизма нитропроизводных органических соединений и селекцию штаммов микроорганизмов, способных к эффективной биотрансформации и биодеградации этих веществ.

В проведенных исследованиях использованы традиционные и современные микробиологические методы. Селекционная работа включала преимущественное применение метода накопительных культур, что связано с тем фактом, что органические нитраты, а особенно нитроароматические соединения, являются труднометаболизируемыми веществами. Для оценки биоразнообразия, идентификации активных изолятов, для поиска новых штаммов-продуцентов ферментов, способных к биотрансформации нитросоединений, поиска генетических последовательностей (в том числе генов ферментов азотного обмена) использованы современные методы генетических и геномных исследований: полимеразная цепная реакция, секвенирование, метагеномный анализа на базе систем NGS Junior (Roshe), Ion Torrent PGM (Applied Biosystems). При исследовании процессов биотрансформации нитросоединений для анализа продуктов использовали современнные химико-аналитические методы: ГХ, ВЭЖХ, ГХ-МС, спектрофотометрию. Для разработки и моделирования процессов биодеструкции и биотрансформации использованы мето- ды адсорбционной иммобилизации культур на пористых носителях и процессы обрастания, образования биопленок.

В результате выполненных исследований проведен сравнительный анализ 57 последовательностей базы данных Genbank и других ресурсов NCBI, соответствующих генам биотрансформации азотсодержащих органических соединений, в частности нитроэстераз, нитроредуктаз и амидаз различных видов бактерий. Сравнение последовательностей генов и филогенетический анализ проводились с применением программных пакетов VectorNTI11, ClustalW, а также оригинального приложения YACWGU 1.5.

Из научной литературы известна способность к биотрансформации и биодеградации нитратов органических соединений некоторыми штаммами бактерий, обладающими нитроэстеразной активностью, такими как Bacillus circulans, Desulfovibrio desulfuricans, Escherichia coli, Pseudomonas fluorescens, Burkholderia, Rhodotorula mucilaginosa, Rhodococcus rubropertinctus, a также грибами Aspergillus fumigatus [12, c. 499-502]. В частности, известна роль нитрилэстераз и редуктаз нитроэфиров в аэробных процессах биодеградации нитросоединений [18, с. 250-256; 20, с. 528-532].

Проведена селекция из образцов природных дерново-луговых супесчаных почв и сточных вод промышленных предприятий Пермского края бактерий, метаболизирующих органические нитраты. Методом накопительной культуры, полученной на основе безазотной солевой среды $\mathrm{N}$ [3, с. 63] с добавлением в качестве селективных субстратов органических нитратов - нитроцеллюлозы и нитроароматических соединений, из естественных природных дерново-луговых почв и техногенно-измененных стоков и грунтов, взятых с территории химических предприятий ФГУП «Пермский пороховой завод», ОАО «Камтэкс-Химпром», ЗАО «Ашленд-МСП» выделены сообщества бактерий, способных к использованию труднометаболизируемых органических 
нитратов (коллоксилин, нитрофенол, нитробензол, динитробензол) в качестве источников углерода и/или азота.

Показана высокая активность консорциумов, выделенных из промышленных стоков Пермского порохового завода и ОАО «Камтэкс-Химпром» при разложении нитроцеллюлозы разной степени нитрования. Из литературы подобный результат известен при использовании сульфатредуцирующих бактерий рода Desulfovibrio, описанном в диссертации О.В. Петровой [6, с. 60-68], однако в случае исследованного нами консорциума наблюдалась более полная утилизация в широком диапазоне физико-химических условий. Номера консорциумов соответствуют номерам образцов грунтов и донных отложений, из которых они были выделены: 1-дерново-подзолистая почва ок. села Городище, вблизи г. Соликамска; 2-грунт, ОАО «Соликамский завод «Урал»; 3-грунт, ФГУП «Пермский пороховой завод»; 4- донные отложения, промышленные стоки ОАО «Камтэкс-Химпром»; 5-донные отложения р. Сюзьвы.

При рассеве на комплексной агаризованной среде получены чистые культуры аэробных гетеротрофных бактерий, способных к исполь- зованию органических нитросоединений в качестве источника азота.

Полученные активные штаммы идентифицированы методами полифазной таксономии и анализа генов 16S PHК как представители актинобактерий родов Rhodococcus (15), в частности, видов Rhodococcus erythropolis (9), Rhodococcus ruber (2), Rhodococcus rodnii (4), родов Arthrobacter (7), Gordona (1), бацилл видов Bacillus pumilus (5) и Bacillus thuringiensis (3), а также протеобактерий Pseudomonas fluorescens (4), Pseudomonas putida (2) и Pseudomonas extremaustralis (2).

Штаммы, обладающие высокой активностью и показавшие стабильные результаты в экепериментах по биодеструкции, показаны в табл. 1.

В результате селекционной работы получены штаммы микроорганизмов, обладающие высокой биодеградативной активностью по отношению к нитроцеллюлозе и ароматическим нитросоединениям. В частности, высокой активностью обладали штаммы Pseudomonas fluorescens N-17, N19 и Pseudomonas putida N-26, а также Rhodococcus erythropolis N-4 и N-14, эффективно утилизирующие нитробензолы и нитроцеллюлозу, выделенные из стоков производства нитроцеллюлозы. В то же время и из природных сред, в частности из

Таблица 1

Культуры бактерий, утилизирующие ароматические нитрилы

\begin{tabular}{|c|c|c|}
\hline Номер штамма & Вид бактерий & Источник образцов почв и донных отложений \\
\hline 4NB & Pseudomonas fluorescens & Донные отложения, стоки ОАО «Камтэкс-Химпром» \\
\hline $4-1 N P$ & Pseudomonas fluorescens & Донные отложения, стоки ОАО «Камтэкс-Химпром» \\
\hline $4-2 N P$ & Pseudomonas extremaustralis & Донные отложения, стоки ОАО «Камтэкс-Химпром» \\
\hline $7-1 R I$ & Pseudomonas putida & Донные отложения р.Сюзьва \\
\hline $2-1 N P$ & Bacillus pumilus & Грунт, ФГУП «Пермский пороховой завод», \\
\hline $2-2 N P$ & Bacillus pumilus & Грунт, ФГУП «Пермский пороховой завод», \\
\hline $2-3 N P$ & Bacillus pumilus & Грунт, ФГУП «Пермский пороховой завод», \\
\hline $2-4 N P$ & Bacillus pumilus & Грунт, ФГУП «Пермский пороховой завод», \\
\hline $3-1 N P$ & Bacillus thuringiensis & Грунт, ФГУП «Пермский пороховой завод», \\
\hline $3-2 N P$ & Bacillus thuringiensis & Грунт, ФГУП «Пермский пороховой завод», \\
\hline $3-3 N P$ & Bacillus thuringiensis & Грунт, ФГУП «Пермский пороховой завод», \\
\hline $7 R I$ & Rhodococcus erythropolis & Донные отложения р.Сюзьва \\
\hline $9 \mathrm{NX}$ & Rhodococcus erythropolis & Донные отложения р.Сюзьва \\
\hline 13 & Rhodococcus erythropolis & Донные отложения р.Сюзьва \\
\hline 42111 & Rhodococcus erythropolis & Донные отложения р.Сюзьва \\
\hline
\end{tabular}


карстового озера Молебное, были выделены штаммы Pseudomonas sp. N52, N53, быстро утилизировавшие коллоксилин. Также установлено, что природные почвы содержат большое количество разнообразных культур прокариот, способных утилизировать ароматические нитраты, хоть и с меньшей скоростью по сравнению с изолятами из промышленных стоков.

Исследована кинетика роста активных штаммов бактерий на среде $\mathrm{N}$ с использованием разных ростовых субстратов (глюкозы, ацетата) в качестве единственного источника углерода и коллоксилина, нитрофенола, нитробензола, динитробензола в качестве источников азота.

Показано, что большинство исследованных актинобактерий способны использовать азот нитрогрупп органических нитроэфиров, как это известно для других микроорганизмов и грибов $[10$, с. 289-295, 14 , с. 39-46; 24, с. 298-300; 25, с. 877-881] Отобранные штаммы поддерживали рост на минеральной среде с коллоксилином, нитрофенолом, динитрофенолом, нитротолуолом в качестве источников азота.

Определяли минимальную подавляющую концентрацию для выделенных штаммов ряда ароматических нитросоединений методом микротитрования в план- шетах. Обнаружено, что культуры Rhodococcus и Arthrobacter наиболее устойчивы к высоким концентрациям нитробензола и нитрофенолов. Нитраты толуола оказались менее токсичны, видимо, вследствие низкой растворимости в водной среде. Коллоксилин не оказывал подавляющего действия на рост бактерий (табл. 2).

Исследована способность селекционированных микроорганизмов утилизировать органические нитраты. Культуры выращивали на минеральной среде, содержащей до 0,25\% ароматических нитратов в качестве единственного источника азота (среда $\mathrm{N}$ с добавлением 0,1\% глюкозы) или углерода и азота. Установлено, что наиболее оптимальным ростовым агентом в данных условиях является нитробензол, обеспечивавший максимальный прирост биомассы (табл. 3).

В то же время установлено, что консорциум бактерий, выделенных из производственных сточных вод, деградирует мононитрофенол в слабощелочной среде $(\mathrm{pH} 7,8)$ в концентрации более 1 ммоль/л за 5 часов, с образованием алифатических карбоновых кислот, что значительно превышает скорость биодеградации, описанную в литературе для штаммов Arthrobacter, Burkholderia и др. [28, с. 877-881].

Таблица 2

\section{Минимальные ингибирующие концентрации (МИК), мг/л нитроароматических субстратов для выделенных культур}

\begin{tabular}{|l|c|c|c|}
\hline \multicolumn{1}{|c|}{ Штамм } & Нитробензол & Нитрофенол & Нитрохинолин \\
\hline Pseudomonas fluorescens 4NB & 125 & 31,3 & 31,3 \\
\hline Pseudomonas fluorescens 4-1NP & 125 & 31,3 & 31,3 \\
\hline Pseudomonas extremaustralis 4-2NP & 125 & 31,3 & 31,3 \\
\hline Pseudomonas putida 2NB & 125 & 31,3 & 31,3 \\
\hline Bacillus pumilus 2-1NP & 62,5 & 31,3 & 31,3 \\
\hline Bacillus pumilus 2-2NP & 62,5 & 31,3 & 31,3 \\
\hline Bacillus pumilus 2-3NP & 62,5 & 31,3 & 62,5 \\
\hline Bacillus pumilus 2-4NP & 125 & 31,3 & 62,5 \\
\hline Bacillus thuringiensis 3-1NP & 125 & 31,3 & 62,5 \\
\hline Bacillus thuringiensis 3-2NP & 125 & 31,3 & 62,5 \\
\hline Bacillus thuringiensis 3-3NP & 125 & 31,3 & 31,3 \\
\hline Rhodococcus erythropolis 9HX & 250 & 62,5 & 62,5 \\
\hline Rhodococcus erythropolis 13 & 250 & 62,5 & 62,5 \\
\hline Rhodococcus erythropolis 7RI & 250 & 62,5 & 62,5 \\
\hline Rhodococcus erythropolis 42III & 250 & 62,5 & 62,5 \\
\hline
\end{tabular}




\section{Способность выделенных культур утилизировать нитроароматические соединения}

\begin{tabular}{|l|c|c|c|c|c|c|}
\hline \multicolumn{1}{|c|}{ Штамм } & HX & $\begin{array}{c}\text { HX+ } \\
\text { глюкоза }\end{array}$ & HФ & $\begin{array}{c}\text { HФ+ } \\
\text { глюкоза }\end{array}$ & HБ & $\begin{array}{c}\text { НБ+ } \\
\text { глюкоза }\end{array}$ \\
\hline Pseudomonas fluorescens 4NB & + & ++ & + & ++ & + & ++ \\
\hline Pseudomonas fluorescens 4-1NP & + & ++ & \pm & + & + & ++ \\
\hline Pseudomonas extremaustralis 4-2NP & + & + & + & ++ & + & ++ \\
\hline Pseudomonas putida 2NB & + & + & + & + & + & ++ \\
\hline Bacillus pumilus 2-1NP & - & + & - & + & + & ++ \\
\hline Bacillus pumilus 2-2NP & - & + & - & + & + & ++ \\
\hline Bacillus pumilus 2-3NP & - & + & - & + & + & ++ \\
\hline Bacillus pumilus 2-4NP & - & + & - & + & + & ++ \\
\hline Bacillus thuringiensis 3-1NP & - & + & - & + & + & ++ \\
\hline Bacillus thuringiensis 3-2NP & - & + & - & + & + & ++ \\
\hline Bacillus thuringiensis 3-3NP & - & \pm & - & + & + & ++ \\
\hline Rhodococcus erythropolis 9HX & + & ++ & \pm & + & + & ++ \\
\hline Rhodococcus erythropolis 13 & \pm & + & + & ++ & + & ++ \\
\hline Rhodococcus erythropolis 7RI & + & ++ & + & ++ & + & ++ \\
\hline Rhodococcus erythropolis 42III & + & ++ & + & ++ & + & ++ \\
\hline HXX-
\end{tabular}

НХ - нитрохинолин; НФ - нитрофенол НБ - нитробензол; ++ хороший рост, ОП540>0,5 через 10 сут. культивирования; + рост, ОП540 от 0,05 до 0,5 через 10 сут. культивирования; \pm слабый рост, ОП540<0,05 через 10 сут. культивирования; - рост отсутствует.

Например, для штамма Burkholderia sp. FDS-1-9 часов в концентрации МНФ 0,6 ммоль/л, рН 7 - трансформация до гидрохинона (табл. 4).

Также высокая скорость роста и биодеградации наблюдалась при использовании в качестве субстрата полимера - коллоксилина. Наиболее активно биотрансформация штаммами родококков проходила при использовании в качестве источника углерода $0,1 \%$ ацетата и $0,25 \%$ нитроароматического соединения или $1-5 \%$ коллоксилина при температуре среды $28-30^{\circ} \mathrm{C}$ и слабощелочных значениях $\mathrm{pH}$ 7,2-8,0.

Полученные данные по нашим культурам согласуются с данными, полученными в работе по биодеградации нитроцеллюлозы при моделировании сложных микроценозов очистных сооружений, в которых интенсификация процесса аэрации и насыщение осадков кислородом воздуха в концентрации не менее 7,7 мг $\mathrm{O}_{2} /$ л, поддержание значений $\mathrm{pH}$ среды биореактора в щелочном диапазоне $(7,8-8,0)$, увлажнение донных осадков до $90 \%$ приводило к эффективному удалению нитроцеллюлозы (НЦ) за 31 сут. не менее $55,1 \%$ [1, с. 33-36].
Однако в случае селекционированных нами культур процесс шел с большей скоростью, что вполне ожидаемо.

Установлено, что большинство бактериальных культур - активных трансформантов - обладало нитроредуктазной активностью. Активность нитроэстеразы обнаружена лишь у двух изолятов, не проявлявших в условиях модельных экспериментов высокой скорости биодеградации. Также выделены сообщества микроорганизмов, осуществляющие в анаэробных условиях восстановление нитрата из нитрогрупп ароматических соединений до аммония, органических аминов и амидов. Проведен метагеномный анализ сред, из которых селекционировали активные культуры: техногенно-измененных сред (производственные стоки пермских химических предприятий, использующих нитросоединения, техногенно-измененные грунты предприятий), а также и естественных сред - карстовых озер, рек, не имеющих существенных химических загрязнителей (Сюзьва, Нытвенский р-н), природных супесчаных дерново-луговых и подзолистых почв. 


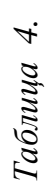

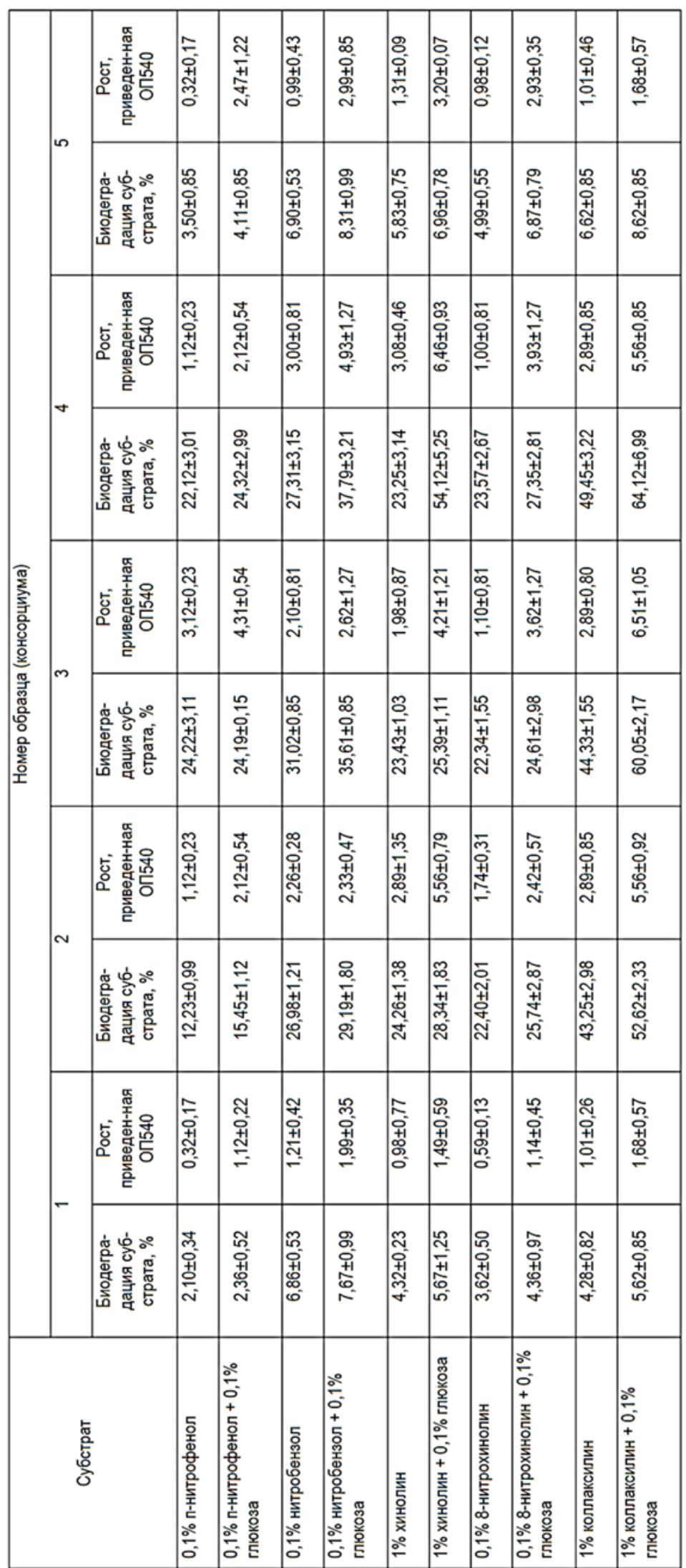


Установлено, что наиболее уникальным является состав метагенома природных карстовых водоемов, а также микроценозов промышленных стоков, содержащих «нитротела». В результате метагеномного анализа установлено, что большая часть выявляемых бактерий в естест венных водоемах относится к филе Proteobacteria - 61\%, представленной в большей мере классом Betaproteobacteria $(37,5 \%$ общей численности), классом Alphaproteobacteria (10,3\% общей численности), классом Deltaproteobacteria (5\% общей численности), классом Gammaproteobacteria (2\% общей численности), классом Epsilonproteobacteria $(0,1 \%$ общей численности), класс Betaproteobacteria представлен порядками Burkholderiales ( $8 \%$ общей численности), семейством Comamonadaceae (5,6\% общей численности); порядком Gallionellales (7,2\% общей численности), семейством Gallionellaceae (7,2\% общей численности) и порядком Rhodocyclales (5\% общей численности), семейством Rhodocyclaceae (5\% общей численности).

Значительная часть выявленных прокариот относилась к филам: Bacteroidetes (14,7\% общей численности), Cyanobacteria $(0,4 \%$ общей численности), Acidobacteria (1,1\% общей численности), Chlorobi (0,6\% общей численности). Сульфатредуцирующие бактерии принадлежат к классу Deltaproteobacteria

$5 \%$ (от общей численности), представленному порядками Desulfuromonadales 0,6\% (от общей численности), Desulfovibrionales 0,5\% (от общей численности), Desulfobacterales $0,5 \%$ (от общей численности). Порядок Desulfuromonadales представлен семейством Geobacteraceae 0,3\% (от общей численности. К порядку Desulfovibrionales относится семейство Desulfovibrionales 0,5\% (от общей численности), $0,5 \%$ (от общей численности). Порядок Desulfobacterales представлен следующими семействами: Desulfobulbaceae 0,2\% (от общей численности), Desulfobulbaceae 0,2\% (от общей численности). Для анализа генов функциональных генов нитроредуктаз и нитро- эстераз использованы праймеры по работе Liang et al. [13, c. 42]:

nemA-F5'-

CAGGCGAAAGGCTATGCGGGCG-3'

nemA-R5'-

GTGTAACCTTCCGCGCGCCCCGTAG-3'

RT-nemA-F5'-

GCCGGTATTCAGGAATGG-3'

RT-nemA-R5'-

GCTCGGACATATGCAGATAAG-3'

nfsA-F5'-

ATGACTCCAACCATTGATTTACTTCGC AGC-3'

nfsA-R5'-TTAGCGCGTGGCCCATCC

CTGTTTATGCAA-3'

RT-nfsA-F5'-

ATTTACAGATTTGCCCCGAT-3'

RT-nfsA-R5'-

ACCGCCTCAATATTATTACG-3'

nfsB-F5'-ATGGATATTGTTTCTGTCGC

CTTAAAACGT-3'

nfsB-R5'-TCAGACTTCCGTCAGGGT

TGTTTCCTG-3'

RT-nfsB-F5'-

TCGTGGATCAAGAAGAGAGC-3'

RT-nfsB-R5'-

AGGAAGTTACCCACGTTGAG-3',

а также праймеры к генам pnrA, pnrB, предложенные на основе анализа генов штамма $P$. putida JLR11 работе Caballero et al. [7, 1217]:

pnrA-F5'-ATTCTAGAGTTATGAGCGTAT ATCTCGG-3'

pnrA-R5'-AAGGATCCGCCACTGGAACCT TGAGTGTC-3'

pnrB-F5'-GAATTCGTATGGATACCGTAT CGCTG-3'

pnrB-R5'-AATTAAGCTTTCAGAGGAAG GTGAACAC-3'.

Также были использованы оригинальные праймеры для обнаружения генов нитроредуктаз типа $n f s A$, характерных для представителей рода Pseudomonas (последовательности в GenBank AF417209.1, AF532911.1 и др.).

Ps_nfsA-F 5'-ATGAGCCTTCAAGACGA AGCACTCA-3'

Ps_nfsA-R 5'-TCAGCGCAGGCCGAAAC CTAG-3'

температура отжига $-60^{\circ}$. 
В результате скрининговых исследований у 6 исследуемых культур с помощью праймеров Ps_nfsA-F/R обнаружены гены, характерные для представителей рода Pseudomonas.

Анализ генов, кодирующих ферменты метаболизма других азотсодержащих соединений, в частности амидаз, проводили, как описано ранее [3, с. 64-65]. Получены данные филогенетического анализа генов амидаз, а также результаты исследования активности, термо- и $\mathrm{pH}-с т а-$ бильности контролируемых ферментативных активностей при трансформации нитроцеллюлозы и ароматических нитратов (нитробензолов, нитротолуолов).

Установлено, что активные штаммы, идентифицированные ранее как Rhodococcus erythropolis и Rhodococcus ruber содержат гены стереоселективных амидаз сигнатурного типа, а представители рода Pseudomonas - последовательности, сходные с генами амидаз Pseudomonas chlororaphis, Pseudomonas fluorescens и Pseudomonas putida 5B [5, с. 1556-1565, 9, с. 382-389].

Получены данные о кинетике биодеградации нитросоединений с использованием выделенных культур микроорганизмов. Показано, что высокоактивные культуры штаммы Pseudomonas sp. N-52, $P$. fluorescens N-17, N19, $P$. putida N-26, $R$. erythropolis N-5 и N-14 в оптимальных условиях 7,7 мг $\mathrm{O}_{2} /$ л, $\mathrm{pH} 7,8-8,0,25^{\circ} \mathrm{C}$ способны трансформировать (разжижать) коллоксилин с высокой скоростью до 0,5 г / 1 г с.в. клеток / сут., что превышает ранее описанные результаты [1,31-36]. Показано, что продуктами трансформации коллоксилина, выделенными микробными сообществами, осуществляющими в анаэробных условиях восстановление нитрата из нитрогрупп ароматических соединений, являются биогенные органические амины и амиды, что дает возможность получать в процессе биодеградации неприродных нитросоединений субстанцию для азотсодержащего органического удобрения.

Исследованы кинетические параметры процессов биотрансформации нитропро- изводных полисахаридов, многоатомных спиртов и ароматических соединений.

Оценивали степень биодеградации субстрата, выраженную в процентах от внесенного в среду количества и рост бактерий, приведенный в единицах оптической плотности при длине волны 540 нм.

Процентное соотношение активных культур, обнаруженных путем ПЦР-анализа и по данным метагеномных исследований, немного отличается, что может быть следствием некультивируемости многих почвенных форм бактерий и накопительным характером данных, получаемых при исследовании метагенома (положительный результат на исследуемую последовательность дают как ДНК из живых клеток, так и ДНК погибших микроорганизмов, оставшаяся в изучаемой среде).

Разработан лабораторный процесс эффективной биодеградации и обезвреживания токсичных органических отходов, содержащих органические нитраты на основе иммобилизованных клеток высокоактивных микроорганизмов, a также их искусственных сообществ. В качестве модельного субстрата использовали 10 мМ 1,3-динитробензол, а модельной системы - проточный колоночный реактор емкостью 200 мл с минеральным наполнителем и сорбированной бактериальной культурой. Показано, что очистка жидкости от растворенного вещества до содержания менее $10 \%$ при циклическом пропускании через биореактор со скоростью 0,2 л/мин при $25^{\circ} \mathrm{C}$ происходит в течение 48 ч.

Смоделированы процессы биотрансформации полимерных нитросоединений с получением азотного биоудобрения на примере коллоксилина. Установлено, что получаемые в результате компостирования продукты биодеградации представляют собой комплексную субстанцию, содержат амидные и аминогруппы. Показано, что на основе 1 г (по сухому весу) коллоксилина в течение 30 сут. ферментации получается 0,92 г (по сухому весу) гетерогенного азотсодержащего полимерного удобрения. Снижение значения 
сухой массы, вероятно, является результатом окислительно-восстановительных и гидролитических реакций, приводящих к потере некоторых групп и частичной деполимеризации субстрата. Установлено, что полученная субстанция достаточно быстро разлагается в почве, повышая скорость роста вегетативной массы модельных растений (перец, томаты). Предварительный анализ на бактериальных тест-системах показал отсутствие токсического и мутагенного действия полученного потенциального удобрения.

Из научной литературы известна способность к биотрансформации нитроцеллюлозы и нитроароматических соединений некоторыми изолятами бактерий, обладающими нитроэстеразной активностью, такими как Bacillus circulans, Desulfovibrio desulfuricans, Escherichia coli, Pseudomonas fluorescens, Rhodococcus rubropertinctus, Rhodotorula mucilaginosa, а также грибами Aspergillus fumigatus. В нашем исследовании получены сообщества микроорганизмов, утилизирующих нитрогруппы коллоксилина с более высокой скоростью, относительно подобных процессов утилизации нитросоединений, известных по данным мировой научной литературы. Впервые смоделированы процессы биотрансформации и биодеградации нитросоединений с получением азотного биоудобрения.

Несмотря на то, что большинство ор- ганических нитросоединений - загрязнителей окружающей среды, имеет техногенное происхождение, достаточно большое количество бактерий и их сообществ, способных использовать эти вещества, высевалось из природных почв и вод, не контактирующих с техногенными органическими нитратами. Это может быть обусловлено отчасти тем фактом, что в открытых системах возможен перенос микроорганизмов из сред, имеющих техногенные загрязнения, а также возможностью переноса следовых количеств нитроорганических соединений. Однако результаты нашего исследования показывают, что очевидной причиной распространения таких систем метаболизма представляется наличие в природных средах некоторых количеств структурных аналогов техногенных загрязнителей, таких, как различные азотсодержашие метаболиты растений и почвенной микрофлоры, а также продукты распада лигнина, в том числе его абиогенной деструкции. И, как известно, природные среды, в том числе богатые почвы, вследствие высочайшего метаболического разнообразия, являются богатейшим источником продуцентов самых разнообразных ферментов.

Полученные результаты могут быть использованы для решения экологических проблем и утилизации некондиционных и смесевых органических субстанций с получением практически полезных продуктов.

\section{Библиографический список}

1. Гладченко М.А., Гайдамака С.Н., Мурыгина В.П., Лифиии А.Б., Черенков П.Г. Исследование процесса твердофазной аэробной ферментации нитроцеллюлозосодержащего осадка сточных вод методом лабораторного моделирования // Химическая физика. - 2015. - Т. 34(6). - С. 30-37.

2. Лазарев Н.В., Левин Э.Н. Лазарев Н.В. Вредные вещества в промышленности. Справочник для химиков, инженеров и врачей. Т. 2. Органические вещества. $-1976 .-724$ с.

3. Максимов А.Ю., Кузнецова М.В., Овечкина Г.В., Козлов С.В., Максимова Ю.Г., Демаков В.А. Влияние нитрилов и амидов на рост и нитрилгидратазную активность штамма Rhodococcus sp. gt $1 / /$ Прикладная биохимия и микробиология, - 2003. - Т. 39. - № 1. - С. 63-68.

4. Максимова Ю.Г., Максимов А.Ю., Демаков В.А. Биотехнологические подходы к биоремедиации окружающей среды, загрязненной тринитротолуолом // Биотехнология. - 2018. - Т. 34. - № 1. - С. 9-23.

5. Периович С.И., Гуранда Д.Т., Поднерняев Д.А., Яненко А.С., Швядас В.К. Алифатическая амидаза из Rhodococcus rhodochrous - представитель семейства нитрилаз/цианидгидратаз // Биохимия. - 2005. T. 70 (11). - C. 1556-1565.

6. Петрова O.E. Трансформация нитроэфира целлюлозы сульфатредуцирующей бактерией Desulfovibrio desulfuricans 1388: дис...канд. биол. наук: Казань, 2004. - 114 с.

7. Caballero A., Lázaro J.J., Ramos J.L., Esteve-Núñez A. PnrA, a new nitroreductase-family enzyme in the TNT-degrading strain Pseudomonas putida JLR11 // Environ Microbiol. - 2005 - Vol. 7(8). - P. 1211-1219. 
8. Erkelens M., Adetutu E.M., Taha M. [et al.] Sustainable remediation - The application of bioremediated soil for use in the degradation of TNT chips // J. Environ. Manage. - 2012. - Vol. 110. - P. 69-76.

9. Fournand D., Arnaud A. Aliphatic and enantioselective amidases: from hydrolysis to acyl transfer activity // J. Appl. Microbiol. - 2001. - Vol. 91(3). - P. 381-393.

10. Gren I., Wojcieszynska D., Guzik U., Perkosz M., Hupert-Kocurek K. Enhanced biotransformation of mononitrophenols by Stenotrophomonas maltophilia KB2 in the presence of aromatic compounds of plant origin // World J. Microbiol. Biotechnol. - 2009. - Vol.26 (2). - P. 289-295.

11. Kumagai $Y$, Wakayama T, Lib S, Shinohara A, Iwamatsu A, Sun G, Shimojo N. Zeta-crystallin catalyzes the reductive activation of 2,4,6-trinitrotoluene to generate reactive oxygen species: a proposed mechanism for the induction of cataracts // FEBS Lett. - 2000. - Vol. 478(3). - P. 295-298.

12. Kulkarni M., Chaudhari A. Microbial remediation of nitro-aromatic compounds: An overview // J. Environmental Management - 2007. - Vol.85 (2). - P. 496-512.

13. Lee B.-U., Park S.-C., Cho Y.-S. [et al.] Expression and characterization of the TNT nitroreductase of Pseudomonas sp. HK-6 in Escherichia coli // Curr. Microbiol. - 2008. - Vol.56. - P.386-390.

14. Liang S.-H., Hsu D.-W., Lin C.-Y. [et al.] Enhancement of microbial 2,4,6-trinitrotoluene transformation with increased toxicity by exogenous nutrient amendment // Ecotoxicol. Environ. Saf. - 2017. - Vol.138. P. 39-46.

15. Littlechild J.A. Enzymes from extreme environments and their industrial applications // Biotechnol. - 2015. P. 1-9.

16. Marvin-Sikkema F.D., de Bont J.A.M. Degradation of nitroaromatic compounds by microorganisms // Applied Microbiology and Biotechnol. - 1994. - Vol. 42. - P. 499-507.

17. Ningthoujam D. Isolation and identification of a Brevibacterium linens strain degrading p-nitrophenol // African J. of Biotech. - 2005. - Vol. 4. - P. 256-257.

18. Nivinskas H., Ronald L. Koder. Two-electron reduction of nitroaromatic compounds by Enterobacter cloacae NAD(P)H nitroreductase: Description of quantitative structure-activity relationships - 2000. Vol. 47. - P. 249 - 258.

19. Ningthoujam D. Isolation and Identification of a Brevibacterium linens strain degrading p-nitrophenol // African Journal of Biotechnology - 2005. - Vol. 4 (3). - P. 256 - 257.

20. Soojhawon I., Lokhande P.D., Kodam K.M., Gawai K.R. Biotransformation of nitroaromatics and their effects on mixed function oxidase system // Enzyme and Microbial Technology - 2005. - Vol. 37 (5). - P. 527-533.

21. Suenaga H., Koyama Y., Miyakoshi M., Miyazaki R., Yano H., Sota M., Ohtsubo Y., Tsuda M., Miyazaki K. Novel organization of aromatic degradation pathway genes in a microbial community as revealed by metagenomic analysis // ISME J. - 2009. - Vol. 3(12): - P. 1335-1348.

22. Suenaga $H$. Targeted metagenomics: a high-resolution metagenomics approach for specific gene clusters in complex microbial communities //Environ Microbiol. - 2012. - Vol. 14(1). - P.13-22.

23. Suenaga $H$. Targeted metagenomics unveils the molecular basis for adaptive evolution of enzymes to their environment // Front Microbiol. - 2015. - Vol. 22 (6): - P. 1018.

24. Xinghui Q., Qiuzan Z., Mei L., Wenqin B., Baotong L. Biodegradation of p-nitrophenol by methyl parathion-degrading Ochrobactrum sp. B2 // International Biodeterioration and Biodegradation - 2007. P. 297-301.

25. Zhang M., Liu G.-h., Song K. [et al.] Biological treatment of 2,4,6-trinitrotoluene (TNT) red water by immobilized anaerobic-aerobic microbial filters // Chem. Eng. J. - 2015. - Vol. 259. - P. 876-884.

\title{
STUDYING THE PROCESSES OF MICROBIAL METABOLISM AND NITRO COMPOUNDS AND THE DEVELOPMENT OF EFFECTIVE BIOCATALYSTS FOR THEIR BIOTRANSFORMATION AND BIODEGRADATION
}

\author{
V.A. Demakov ${ }^{1}$, A.Yu. Maksimov ${ }^{1}$, Yu.G. Maksimova ${ }^{1}$, A.I. Halitova ${ }^{2}$, A.V. Shilova ${ }^{2}$, \\ A.S. Litasova ${ }^{2}$, Yu.A. Pavlova ${ }^{1}$, S.V. Kozlov ${ }^{1}$, G.V. Ovechkina ${ }^{1}$ \\ ${ }^{1}$ Institute of Ecology and Genetics of Microorganisms UB RAS \\ ${ }^{2}$ Perm Federal Research Center UB RAS
}

As a result of selection from communities of natural and technologically modified environments, communities of aerobic heterotrophic bacteria were identified, that are capable of using labormetabolizable natural nitrates (colloxylin, nitrophenol, nitrobenzene, dinitrobenzene) as sources of carbon and/or nitrogen. Active cultures were obtained, identified as actinobacteria of the genera Rhodococcus (Rhodococcus erythropolis, Rhodococcus ruber, Rhodococcus rodnii), Arthrobacter, 
Gordona, bacilli of the species Bacillus pumilus and Bacillus thuringienses, saliva, pinching, and mucous larch to nitrocellulose and aromatic nitro compounds.

A metagenomic analysis of microcenoses of technologically altered soils and Perm production plants has been carried out using the nitro compound of the Federal State Unitary Enterprise Perm Powder Plant, OJSC Solikamsk Plant Ural, OJSC Kamtex-Khimprom, as well as natural medium-sized rivers and karst lakes, natural resources of sod-meadow and podzolic soils. As a result of PCR analysis of active cultural proteobacteria, genes of nitroreductases were found that are characteristic of some representatives of the genus Pseudomonas. It was shown that the isolated Pseudomonas and Rhodococcus isolates possess amidase activity and have gene types of known amidases.

The growth kinetics of active cultures using ordinary nitrates as a substrate was studied. A certain influence of cultivation conditions (temperature, $\mathrm{pH}$, salt composition) on the growth rate, biomass growth and activity of biodegradation of nitro compounds has been determined. It was shown that highly active cultures of Pseudomonas fluorescens, P. putida, R. erythropolis under optimal conditions are capable of depolymerizing colloxylin at a high rate of up to 0,5 g / $1 \mathrm{~g}$ d.v. cells / day. It was established that the derivatives of biotransformation are microbial communities of colloxylins, biogenic organic amines and amides, which makes it possible to obtain a substrate for nitrogen-containing organic fertilizer during biodegradation.

Keywords: bacteria, biocatalysis, bio-purification, biotransformation, nitro compounds, nitrotoluene, nitrocellulose, TNT.

\section{Сведения об авторах:}

Демаков Виталий Алексеевич, член-корреспондент РАН, доктор медицинских наук, профессор, директор ИЭГМ УрО РАН, заведующий лабораторией молекулярной микробиологии и биотехнологии, Институт экологии и генетики микроорганизмов УрО РАН - филиал Пермского федерального исследовательского центра УрО РАН (ИЭГМ УрО РАН), 614081, г. Пермь, ул. Голева, 13; e-mail: demakov@iegm.ru

Максимов Александр Юрьевич, кандидат биологических наук, доцент, старший научный сотрудник лаборатории молекулярной микробиологии и биотехнологии, ИЭГМ УрО РАН; e-mail: alm@iegm.ru Максимова Юлия Геннадьевна, доктор биологических наук, ведущий научный сотрудник лаборатории молекулярной микробиологии и биотехнологии, ИЭГМ УрО РАН; e-mail: yull_max@mail.ru

Халитова Азалия Ильдаровна, младший научный сотрудник лаборатории агробиофотоники, Пермский федеральный исследовательский центр УрО РАН (ПФИЦ УрО РАН), 614900, г. Пермь, ул. Ленина, 13А; e-mail: khalitova95@mail.ru

Шилова Анна Владимировна, младший научный сотрудник лаборатории агробиофотоники, ПФИЦ УpO PAH; e-mail: A.Shilova-IEGM@yandex.ru

Литасова Алена Сергеевна, младший научный сотрудник лаборатории агробиофотоники, ПФИЦ УpO PAH; e-mail: alyona12.92@mail.ru

Павлова Юлия Андреевна, кандидат биологических наук, младший научный сотрудник лаборатории молекулярной микробиологии и биотехнологии, ИЭГМ УрО РАН; e-mail: pavlova_ua@mail.ru Козлов Сергей Васильевич, кандидат биологических наук, научный сотрудник лаборатории молекулярной микробиологии и биотехнологии, ИЭГМ УрО РАН; e-mail: kozlov@mail.ru

Овечкина Галина Вячеславовна, ведущий инженер лаборатории молекулярной микробиологии и биотехнологии, ИЭГМ УрО РАН; e-mail: ovechkina@mail.ru 